\title{
Inclusions of $(\mathrm{Mg}, \mathrm{Fe}) \mathrm{O}$ in Mantle Diamonds
}

Harte, B. ${ }^{~}$, Hutchison, M. T. ${ }^{1}$, Lee, M. ${ }^{1}$ and Harris, J. W. ${ }^{2}$

1. Department of Geology and Geophysics, University of Edinburgh, King's Buildings, Edinburgh EH9 3JW, U. K.

2. Department of Geology and Applied Geology, University of Glasgow, Glasgow G12 8QQ, U. K

\section{Introduction}

Accepting the general evidence that mantle rock chemical compositions are dominantly peridotitic or eclogitic, oxides of the $\mathrm{MgO}-\mathrm{FeO}$ (periclase-wustite) solid solution series are only expected under normal mantle physical conditions at depths equal to, or greater than, those of the breakdown of the $(\mathrm{Mg} . \mathrm{Fe})_{2} \mathrm{SiO}_{4}$ polymorphs at the boundary between upper and lower mantle. Since the ( $\mathrm{Mg} . \mathrm{Fe}) \mathrm{O}$ inclusions occurring in diamonds are dominantly $\mathrm{Mg}$-rich we shall refer to them as ferropericlase (fPer). Inclusions of fPer in diamonds are recorded from at least nine localities: Orroroo, Monastery, Koffiefontein, Sloane, São Luiz, River Ranch, Letseng-La-Terai, Guinea and Mwadui. At present, São Luiz dominates the recorded sample and it is the São Luiz fPer inclusions which are of particular concern in this paper.

In support of a lower mantle origin for fPer inclusions, particular attention has previously been drawn to the potential association of fPer with MgSi-perovskite as inclusions in diamonds, (ScottSmith et al., 1984; Moore et al., 1986); and such evidence is again seen most widely in the São Luiz inclusion suite where not only MgSi-perovskite, but also CaSi-perovskite and a phase of garnet composition, are seen in association with fPer (Harte and Harris, 1994; Harris et al, 1997, Hutchison. 1997). This association and the fact that the MgSi-perovskite is usually relatively Alpoor suggests a derivation largely from the shallowest part of the lower mantle (Harris et al., 1997), and this possibility may be supported by the occurrence of some unusual pyroxene-like inclusions (Hutchison, 1997). However, this inference may relate more to the time of encapsulation of material in the diamonds and need not imply the initial point of origin of that material. We raise the possibility below that some fPer material may derive in part from the D" layer at the base of the lower mantle.

\section{Major, minor and trace element compositions.}

Electron microprobe analysis of all the São Luiz fPer inclusions has been carried out at Edinburgh University. Mössbauer spectroscopy to yield $\mathrm{Fe}^{3+} /\left(\mathrm{Fe}^{2+}+\mathrm{Fe}^{3+}\right)$ ratios has been done on five São Luiz IPer inclusions at Bayerisches Geoinstitut (McCammon et al., 1997). The Mossbauer data show that nearly all $\mathrm{Fe}$ in the fPer is $\mathrm{Fe}^{2+}$, with $\mathrm{Fe}^{3+} /\left(\mathrm{Fe}^{2+}+\mathrm{Fe}^{3+}\right)$ most commonly being $2 \%$. The Sao Luiz inclusions show an unusually wide range of $\mathrm{Mg} /\left(\mathrm{Mg}+\mathrm{Fe}^{2+}\right)$ from 0.38 to 0.85 with many inclusions showing values of $<0.80$ (Fig. 1). This contrasts markedly with fPer inclusions from other localities (Guinea. Koffiefontein, Letseng-La-Terai, Orrorroo, Sloane), with $\mathrm{Mg} /\left(\mathrm{Mg}+\mathrm{Fe}^{2+}\right)$ usually $>0.85$; the most magnesian (McDade and Harris, this volume) having $0.89 \mathrm{Mg} /\left(\mathrm{Mg}^{2} \mathrm{Fe}^{2+}\right)$. Only the Monastery fPer shows $\mathrm{Mg} /\left(\mathrm{Mg}+\mathrm{Fe}^{2+}\right)$ extending to lower values than São Luiz (Fig. 1).

Apart from $\mathrm{MgO}$ and $\mathrm{FeO}$, other elements are of minor amount with maximum wt\% values in the São Luiz inclusions as follows: $\mathrm{TiO}_{2} 0.1, \mathrm{Al}_{2} \mathrm{O}_{3} 0.3, \mathrm{Cr}_{2} \mathrm{O}_{3}$ 2.6, $\mathrm{MnO}$ 0.8, $\mathrm{NiO}$ 1.5, and $\mathrm{Na}_{2} \mathrm{O}$ 1.3. There is a positive correlation of $\mathrm{NiO}$ with $\mathrm{MgO}$ content, and $\mathrm{Cr}$ may be more abundant in $\mathrm{Mg}$-rich fPer although the correlation is poor. Trace element concentrations in the fPer are low, yielding values which are chondritic or subchondritic (Harte et al., 1994; Hutchison, 1997). For the REE, Y, $\mathrm{Zr}$ and $\mathrm{Sr}$ there is a general tendency for concentrations to decrease with decreasing $\mathrm{Mg} /\left(\mathrm{Mg}+\mathrm{Fe}^{2+}\right)$. 


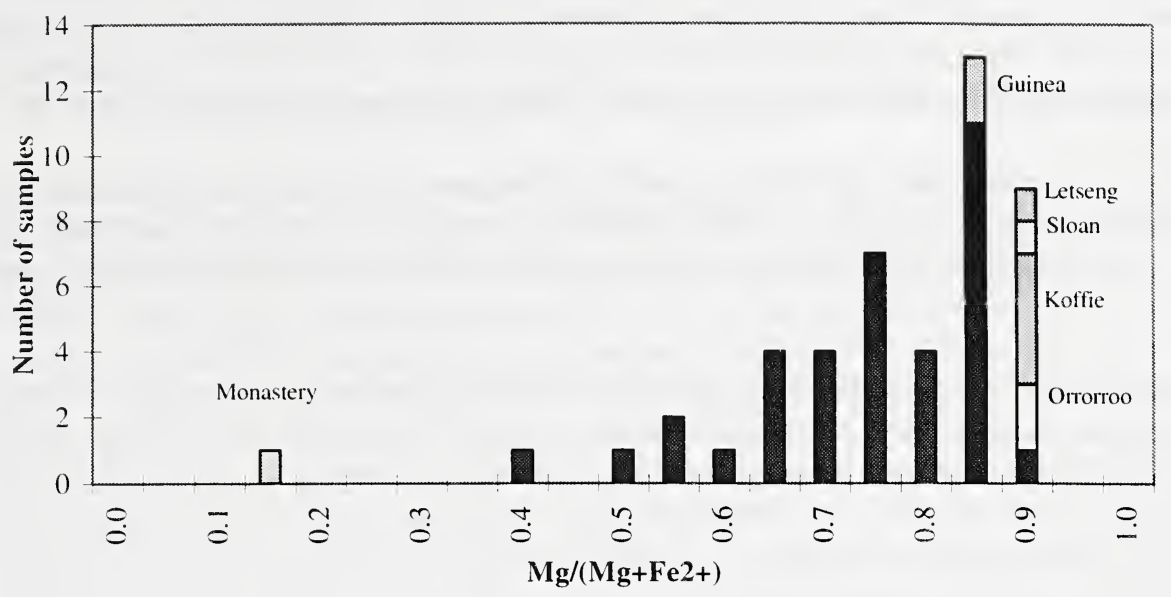

Fig. 1. Distribution of $\mathrm{Mg} /\left(\mathrm{Mg}+\mathrm{Fe}^{2+}\right)$ composition for fPer inclusions in diamonds from São Luiz (dark grey) and other worldwide sources (pale grey with labels according to locality; 'Koffie' refers to Koffiefontein).

\section{Inclusions within the Sao Luiz (Mg,Fe)O grains}

BSE observations made by SEM (for atomic number contrast) on fPer inclusions from São Luiz indicate that approximately a quarter of them contain very small elongate bodies, which have a high back-scatter intensity. These bodies are typically around 1 to $3 \mu \mathrm{m}$ in length and $<0.4 \mu \mathrm{m}$ wide, and sometimes appear to be linked together in chains and may show rough alignments. Their textural arrangements and size are suggestive of exsolved material nucleated in dislocation arrays. In one case (BZ67) the tiny elongate bodies appear to have coalesced into sinuous linear arrays, possibly like subgrain walls. TEM investigation of one specimen shows that the elongate bodies have crystal structure reflections agreeing well with spinels of the $\mathrm{MgO} \cdot \mathrm{Fe}_{2} \mathrm{O}_{3}$ to $\mathrm{FeO} \cdot \mathrm{Fe}_{2} \mathrm{O}_{3}$ (magnesioferrite to magnetite) solid solution series. Chemical analysis by TEM of inclusions and by SEM of the sinuous linear arrays in BZ67 strongly suggests an essentially $\mathrm{MgO} \mathrm{Fe}_{2} \mathrm{O}_{3}$ composition ( $>95 \%$ of the magnesioferrite molecule) for the inclusions.

The generally low $\mathrm{Fe}^{3+}$ contents of the fPer are consistent with experimental work showing restriction of the solid solution of $\mathrm{Fe}^{3+}$ in fPer at high pressures (McCammon et al., 1995, and in press). The phase equilibria suggest that the following may be responsible for $(\mathrm{Mg}, \mathrm{Fe}) \mathrm{O} . \mathrm{Fe}_{2} \mathrm{O}_{3}$ exsolution: (1) increasing pressure; (2) decreasing temperature (but probably unlikely in an adiabatic geothermal gradient where it would need to offset the potential counter-effect of decreasing pressure); (3) increasing $f_{2}$. If the exsolution is a response to changing $f_{\mathrm{O}_{2}}$ then it would almost certainly have to happen before encapsulation of the fPer in diamond because of the slowness of oxygen diffusion into diamond.

\section{Possibilities of a D" origin - a discussion with a lot of 'ifs'.}

A most striking aspect of the São Luiz fPer is their wide range of $\mathrm{Mg} /\left(\mathrm{Mg}+\mathrm{Fe}^{2+}\right)$ compositions. The normal way of generating high-Fe compositions in the mantle is by crystal and melt partitioning and fractionation, but the composition range seen at São Luiz is extremely large, even if eclogitic or basic igneous starting compositions are used rather than peridotitic ones. Within the lower mantle itself melting processes are unlikely given the high potential melting temperatures compared with 
likely geothermal gradients (Zerr and Boehler, 1994); though this problem might be averted by imagining the differentiation processes as occurring in the upper mantle and being transported to the lower mantle by convection or subduction. However, another difficulty facing a melt fractionation process is that the more Fe-rich fPer inclusions appear to have come from an environment less-rich in incompatible elements than the magnesian fPer, which is the opposite of what might be expected.

A potential way round the high Fe/Mg problem of some fPer would be to speculate that these compositions had come from the D" zone of the mantle adjacent to Earth's outer core. Knittle and Jeanloz (1991) and Zerr and Boehler (1994) have noted from experimental data the potential for interaction of $(\mathrm{Mg}, \mathrm{Fe}) \mathrm{O}$ with molten $\mathrm{Fe}$ at the core-mantle boundary. It also seems likely that D" is involved in lower mantle convection processes (e.g. Loper and McCartney, 1986), and this necessarily implies the movement of D" material to shallower regions of the mantle. The amount of Fe-rich material moved would doubtless be limited by gravitational effects, but the fPer inclusions are generally $<200 \mu \mathrm{m}$ across. If mantle convection is layered with a boundary at the lower/upper mantle junction, then material from D" may become entrained along that junction at a similar level to that from which silicates of the Sao Luiz lower mantle suite appear to derive. Encapsulation in diamond would preserve distinctive Fe-rich compositions before they were lost by mixing with normal more Mg-rich mantle material. With a layered mantle convection system of the type described, the uppermost part of the lower mantle would also form part of a thermal boundary, within which relatively strong temperature gradients (rather than the adiabatic ones of the vertical limbs of the convective system) might cause the $(\mathrm{Mg}, \mathrm{Fe}) \mathrm{O} . \mathrm{Fe}_{2} \mathrm{O}_{3}$ exsolution from $(\mathrm{Mg}, \mathrm{Fe}) \mathrm{O}$. If $\mathrm{Fe}-$ rich ( $\mathrm{Mg} . \mathrm{Fe}) \mathrm{O}$ inclusions in diamonds have partly come from $\mathrm{D}$ ", they may provide evidence of layered mantle convection.

\section{References}

Harris, J.W., Hutchison, M.T., Hursthouse, M., Light, M., and Harte, B., 1997, A new tetragonal silicate mineral occurring as inclusions in lower mantle diamonds. Nature, 387, p. 486-488.

Harte, B., Hutchison, M.T., and Harris, J.W., 1994, Trace element characteristics of the lower mantle: a study of inclusions in diamonds from São Luiz, Brazil. Mineral. Mag., 58A, p. 386-387.

Harte, B., and Harris, J.W., 1994, Lower mantle mineral associations preserved in diamonds. Mineral. Mag.. 58A, p. 384-385.

Hutchison, M. T., 1997 Constitution of the sub-lithospheric mantle shown by diamonds and their inclusions. Unpublished PhD Thesis, University of Edinburgh.

Loper. D.E., and McCartney, K., 1986, Mantle plumes and the periodicity of of magnetic field reversals. Geophys. Res. Lett., 13, p. 1525.

Knittle, E., and Jeanloz, R., 1991, Earth's core-mantle boundary: results of experiments at high pressures and temperatures. Science, 251, p. 1438-1443.

McCammon, C. A., Harris, J. W., Harte, B. and Hutchison, M. T., 1995, Ferric iron content of (Fe,Mg)O from lower mantle inclusions: Plume 2, Terra Abstracts, 3, p. 91-94.

McCammon, C., Hutchison, M. T. and Harris, J. W., 1997, Ferric iron content of mineral inclusions in diamonds from São Luiz: A view into the lower mantle: Science, 278, p. 434-436

Moore, R. O., Otter, M. L., Rickard, R. S., Harris, J. W. and Gurney, J. J., 1986, The occurrence of moissanite and ferro-periclase as inclusions in diamond: Abs. Geol. Soc. Aust., 16, p. 409-411

Scott-Smith, B., Danchin, R., Harris, J.W., and Stracke, K., 1984, Kimberlites near Orroroo, South Australia: In: Kimberlites I: (Ed.. Kornprobst, J.). Elsevier, Amsterdam, p. 121-142.

Zerr. A., and Boehler, R., 1994, Constraints on the melting temperature of the lower mantle from high-pressure experiments on $\mathrm{MgO}$ and magnesiowustite. Nature, 371, p. 506-508. 